\title{
Global transcriptional response to mammalian temperature provides new insight into Francisella tularensis pathogenesis Joseph Horzempa ${ }^{1}$, Paul E Carlson Jr1 ${ }^{1}$, Dawn M O'Dee ${ }^{1}$, Robert MQ Shanks',2 and Gerard J Nau*1,3,4
}

\begin{abstract}
Address: ${ }^{1}$ Department of Microbiology and Molecular Genetics, University of Pittsburgh School of Medicine, Pittsburgh, PA 15261, USA, ${ }^{2}$ Charles T. Campbell Laboratory of Ophthalmic Microbiology, Department of Ophthalmology, University of Pittsburgh Eye Center, Pittsburgh, PA 15213, USA, ${ }^{3}$ Department of Medicine, Division of Infectious Diseases, University of Pittsburgh School of Medicine, Pittsburgh, PA 15261, USA and ${ }^{4}$ Center for Vaccine Research, University of Pittsburgh School of Medicine, Pittsburgh, PA 15261, USA
\end{abstract}

Email: Joseph Horzempa - horzempa@pitt.edu; Paul E Carlson - pec25@pitt.edu; Dawn M O'Dee - dmo8@pitt.edu; Robert MQ Shanks - shanksrm@upmc.edu; Gerard J Nau* - gjnau@pitt.edu

* Corresponding author

Published: 8 October 2008

BMC Microbiology 2008, 8:172 doi:10.1/86/147|-2/80-8-172
Received: 16 May 2008

Accepted: 8 October 2008

This article is available from: http://www.biomedcentral.com/I47I-2/80/8/I72

(C) 2008 Horzempa et al; licensee BioMed Central Ltd.

This is an Open Access article distributed under the terms of the Creative Commons Attribution License (http://creativecommons.org/licenses/by/2.0), which permits unrestricted use, distribution, and reproduction in any medium, provided the original work is properly cited.

\begin{abstract}
Background: After infecting a mammalian host, the facultative intracellular bacterium, Francisella tularensis, encounters an elevated environmental temperature. We hypothesized that this temperature change may regulate genes essential for infection.

Results: Microarray analysis of $F$. tularensis LVS shifted from $26^{\circ} \mathrm{C}$ (environmental) to $37^{\circ} \mathrm{C}$ (mammalian) showed $\sim 11 \%$ of this bacterium's genes were differentially-regulated. Importantly, $40 \%$ of the protein-coding genes that were induced at $37^{\circ} \mathrm{C}$ have been previously implicated in virulence or intracellular growth of Francisella in other studies, associating the bacterial response to this temperature shift with pathogenesis. Forty-four percent of the genes induced at $37^{\circ} \mathrm{C}$ encode proteins of unknown function, suggesting novel Francisella virulence traits are regulated by mammalian temperature. To explore this possibility, we generated two mutants of loci induced at $37^{\circ} \mathrm{C}$ [FTL_I58I and FTL_1664 (deoB)]. The FTL_158I mutant was attenuated in a chicken embryo infection model, which was likely attributable to a defect in survival within macrophages. FTL_I58I encodes a novel hypothetical protein that we suggest naming temperature-induced, virulenceassociated locus $A$, tivA. Interestingly, the deoB mutant showed diminished entry into mammalian cells compared to wild-type LVS, including primary human macrophages and dendritic cells, the macrophage-like RAW 264.7 line, and non-phagocytic HEK-293 cells. This is the first study identifying a Francisella gene that contributes to uptake into both phagocytic and non-phagocytic host cells.
\end{abstract}

Conclusion: Our results provide new insight into mechanisms of Francisella virulence regulation and pathogenesis. F. tularensis LVS undergoes considerable gene expression changes in response to mammalian body temperature. This temperature shift is important for the regulation of genes that are critical for the pathogenesis of Francisella. Importantly, the compilation of temperatureregulated genes also defines a rich collection of novel candidate virulence determinants, including tivA (FTL_I58I). An analysis of tivA and deoB (FTL_1664) revealed that these genes contribute to intracellular survival and entry into mammalian cells, respectively. 


\section{Background}

Francisella tularensis is a Gram-negative bacterium that is pathogenic to humans [1]. This organism causes mortality in up to $60 \%$ of infected individuals if untreated [2]. Based on the potential to weaponize this organism, the Center for Disease Control and Prevention has classified F. tularensis as a Category A biodefense agent [3]. It is therefore vital to understand how this organism responds to environmental and host signals, and how these cues alter expression of virulence determinants. During the course of a natural Francisella infection, this bacterium may transition from an amoeba [4] or an arthropod host [5] to colonize human cells. Accompanying this transition, it is likely that chemical and physical signals alert Francisella that it has entered a mammalian host.

The manner by which $F$. tularensis integrates environmental stimuli to regulate gene expression is fundamental to the success of this organism as an intracellular pathogen. The most well-studied virulence factors of $F$. tularensis are encoded in the Francisella Pathogenicity Island (FPI) [6]. The amount of one of the virulence proteins encoded in this cluster, IglC, increases in response to growth in macrophages and hydrogen peroxide [7]. In addition, iron limitation has been shown to induce transcription and protein levels of IglACD and $\operatorname{PdpB}[8,9]$ as well as stimulate siderophore production by F. tularensis [10]. Previously, we have shown that differing culture conditions greatly influence host-pathogen interactions and the ability of $F$. tularensis live vaccine strain (LVS) to activate macrophages [11].

Prior to the current study, there has only been a single published report characterizing the global transcriptional Francisella response to an environmental cue, specifically iron limitation [8]. Important insights into the regulation of virulence factors like iglC were defined in this analysis. However, numerous genes associated with virulence by other studies are not affected by different iron concentrations [8,12-15]. Because F. tularensis may transition between hosts, mammalian body temperature is another signal that is likely to be critical for this pathogen.

Pathogenic bacteria that encounter a shift in temperature during their life cycle sometimes respond with enhanced virulence factor expression [16-19]. However, there are discrepancies among the specific groups of genes that are affected by temperature and the mechanism of regulation between organisms. For example, Shigella increases production of its Type III secretion system in response to mammalian temperature [20]. The homologous secretion apparatus in pathogenic Salmonella, however, is not regulated by temperature [21]. Regarding the mechanism of regulation, genes involved in the heat-shock response are often induced at mammalian temperatures relative to those of the environment. This regulation is usually due to the presence of a conserved inverted repeat regulatory structure in the promoter region [22], or control by a $\sigma^{32}$ type heat shock sigma factor [23]. In contrast, the bacterium responsible for whooping cough, Bordetella pertussis, uses a two-component system comprised of BvgS and BvgA to alter transcription of genes in response to temperature. Following induction of $b v g A S$ at $37^{\circ} \mathrm{C}$, phosphorylation by BvgS allows BvgA-binding to promoter regions of virulence genes, such as the adhesin, fimX [24]. Given the uncertainty of target temperature-regulated genes and differences in mechanism among bacteria, it is necessary to define the temperature regulon in individual species. Studying gene expression changes induced by a shift to mammalian temperature could provide valuable insight into Francisella virulence.

A few previous studies have investigated the Francisella response to temperature at the molecular level. High temperature $\left(42-44^{\circ} \mathrm{C}\right)$ synonymous with heat stress has been shown to have dramatic effects on $F$. tularensis gene and protein expression [25-27] including increased production of the heat shock proteins GroEL, GroES, DnaK, and ClpB [27]. Heat stress has also been shown to enhance the virulence of a mutant form of F. tularensis LVS [28]. Interestingly, F. novicida has been shown to alter its outer membrane at $25^{\circ} \mathrm{C}$ versus $37^{\circ} \mathrm{C}$ by differentially modifying the lipid A component of the lipopolysaccharide [29]. In addition, it has been observed that virulent $F$. tularensis clinical isolates increase the mannose modification of their lipopolysaccharide when cultivated at temperatures less than $25^{\circ} \mathrm{C}$ [30]. The results from these previous studies suggest that a global transcript analysis following a shift to mammalian body temperature should reveal gene regulation that is critical to Francisella pathogenesis.

Here we show that a shift from environmental to mammalian body temperature significantly alters the transcriptome of F. tularensis LVS. Many genes that we identified as significantly induced at $37^{\circ} \mathrm{C}$ have been previously implicated in Francisella virulence, supporting the notion that this temperature shift is important for the regulation of pathogenesis. We provide evidence that the product of a gene encoding the hypothetical protein most profoundly induced by mammalian temperature contributes to virulence and intracellular growth. Moreover, data presented here indicate that a locus up-regulated at $37^{\circ} \mathrm{C}$ was required for optimal uptake by eukaryotic cells. This is the first $F$. tularensis gene identified to be involved in the entry of this organism into both phagocytic and non-phagocytic host cells. The results from this study support a model where detection of mammalian body temperature by $F$. tularensis is important for regulation of physiology necessary for successful infection. 


\section{Results}

\section{F. tularensis LVS global temperature regulation}

To study Francisella gene expression changes associated with exposure to mammalian temperature, we conducted a microarray analysis of LVS as a model $F$. tularensis strain (Table 1). Gene expression of LVS cultured at $26^{\circ} \mathrm{C}$ (nonmammalian environment) was compared to bacteria shifted to $37^{\circ} \mathrm{C}$ (mammalian host body temperature). Labeled cDNA target was produced from RNA isolated from F. tularensis LVS and was subsequently hybridized to a custom Agilent Francisella microarray. Global gene expression data were analyzed with a J5 statistical test, which was selected to limit the number of false positives [31]. This analysis identified 95 genes with significantly increased expression and 125 genes with decreased expression in response to a shift to mammalian body temperature (see additional files 1 and 2, respectively). Collectively, this represents approximately $~ 11 \%$ of the genes in the entire LVS genome. Genes with a significant change in expression were examined with the Gene Pattern program by hierarchical clustering (Fig. 1). The clustered data exhibited a distinct pattern of transcript induction and repression in response to mammalian body temperature (Fig. 1). Together, these data indicate that this temperature shift has a broad impact on F. tularensis transcription.

The microarray data were confirmed using quantitative real time PCR (Q-PCR), in which eight differentially-

Table I: Strains, plasmids, and primers used in this study.

\begin{tabular}{|c|c|c|}
\hline $\begin{array}{l}\text { Strain, plasmid, } \\
\text { or primer }\end{array}$ & Description & $\begin{array}{l}\text { Source or } \\
\text { Reference }\end{array}$ \\
\hline \multicolumn{3}{|l|}{ Strains } \\
\hline \multicolumn{3}{|l|}{ F. tularensis } \\
\hline LVS & F. tularensis subsp. holartica live vaccine strain & Karen Elkins \\
\hline$|58| d$ & LVS with FTL_I 581 disruption, $\mathrm{Hyg}^{\mathrm{R}}$ & This study \\
\hline 1664d & LVS with FTL_I664 (deoB) disruption, HygR & This study \\
\hline \multicolumn{3}{|l|}{ E. coli } \\
\hline XLI0-Gold & $\begin{array}{l}\Delta(m c r A) / 83 \Delta(m c r C B-h s d S M R-m r r) / 73 \text { endA I supE44 thi-I recAl gyrA96 relA I lac Hte [F' proAB laclaZDMI } 5 \\
\left.\left.\text { TnI0 (Tet }{ }^{R}\right) \text { Amy Cam }\right]\end{array}$ & Stratagene \\
\hline $\mathrm{DH} 5 \alpha$ & F- $\phi 80$ lacZ $\Delta M I 5 \Delta$ (lacZYA-argF) UI69 recAI endAI hsdR I7 $\left(r_{k^{-}}, \mathrm{m}_{\mathrm{k}}+\right)$ phoA supE44 $\lambda$-thi-I gyrA96 relA I & Invitrogen \\
\hline JMI09 & endAI, recAI, gyrA96, thi, hsdRI7 $\left(\mathrm{r}_{\mathrm{k}}^{-}, \mathrm{m}_{\mathrm{k}}{ }^{+}\right)$, relAI, supE44, $\Delta($ lac-proAB), [F' traD36, proAB, laqlaZ $\Delta \mathrm{MI} 5]$ & Promega \\
\hline \multicolumn{3}{|l|}{ Plasmids } \\
\hline pFNLTP8 & Francisella shuttle plasmid, $A p^{R}, K^{R}$ & [63] \\
\hline PRK2013 & Helper plasmid for triparental mating, $\mathrm{Km}^{\mathrm{R}}$ & {$[64]$} \\
\hline PMP6I5 & Francisella shuttle plasmid, HygR & {$[65]$} \\
\hline PMQI3Ihyg & $\begin{array}{l}\text { F. tularensis suicide vector, } \mathrm{pBBR} \text { I ori, oriT, contains the hyg cassette driven by the groEL promoter from } \\
\text { PMP6I5, oriT, } \mathrm{Km}^{\mathrm{R}}, \mathrm{Hyg}^{\mathrm{R}}\end{array}$ & This study \\
\hline PMQI3IhygI58Id & PMQ I I Ihyg with the central 560 base pair region of FTL_I58I & This study \\
\hline PMQI3IhygI664d & PMQ I I hyg with the central 900 base pair region of FTL_I664 (deoB) & This study \\
\hline PFTL_1581 & $\begin{array}{l}\text { Broad-host-range vector, } \mathrm{PCI} 94 \text { ori, contains cloned } \mathrm{FTL} I 58 \mathrm{I} \text { along with } 600 \text { base pairs upstream and } 100 \\
\text { base pairs downstream of this gene, complementing plasmid, } \mathrm{Ap}^{\mathrm{R}}, \mathrm{Cam}^{\mathrm{R}}\end{array}$ & This study \\
\hline pF8AX & pFNLTP8 $\Delta n p t, A p^{R}$ & This study \\
\hline pF8CAT & pF8AX with cat, $A p^{R}, C a m^{R}$ & This study \\
\hline PFTL_I664 & $\begin{array}{l}\text { PF8CAT with cloned FTL_I } 664(\mathrm{deoB}) \text { along with } 600 \text { base pairs upstream and } 100 \text { base pairs downstream } \\
\text { of this gene, complementing plasmid }\end{array}$ & This study \\
\hline \multicolumn{3}{|l|}{ Primers } \\
\hline I58I_560F & 5'-ATGGATCCTGAGCTAAATGATGCTTTAGTATCTC-3' & Invitrogen \\
\hline I58I_560R & 5'-ATGGTACCAAGACGACATAGCCACG-3' & Invitrogen \\
\hline 1664_900F & 5'-ATGGATCCGAACCTGGAGCAGTTGAAT-3' & Invitrogen \\
\hline I664_900R & 5'-ATGGTACCTAAGAAAGTTGCGGAATATAATAGATG-3' & Invitrogen \\
\hline I58I_clone_up & 5'-GATCGGATCCAGGTCAATCAGGAGTTGG-3' & Invitrogen \\
\hline |58|_clone_down & 5'-GATCGGTACCCACCTATTTGAATTAAAAAGAAGTTTATACAC-3' & Invitrogen \\
\hline 1664_clone_up & 5'-GATCGGATCCGATGGCTATGGTATATCTTCGG-3' & Invitrogen \\
\hline 1664_clone_down & 5'-GATCGGTACCACCGAGAGAATTTCTCGC-3' & Invitrogen \\
\hline F8Agel & 5'-CATTAGACCGGTGCGAAACGATCCTCATCCTGTC-3' & Invitrogen \\
\hline F8Xhol & 5'-Phosphorylated - CATTAGCTCGAGGGAAGAGTATGAGTATTCAAC-3' & Invitrogen \\
\hline XholCAT & 5'-CATGCTCGAGTTATAAAAGCCAGTCATTAGGCC-3' & Invitrogen \\
\hline AgelCAT & 5'-CATGACCGGTATGAACTTTAATAAAATTGATTTAGACAATTGG-3' & Invitrogen \\
\hline
\end{tabular}




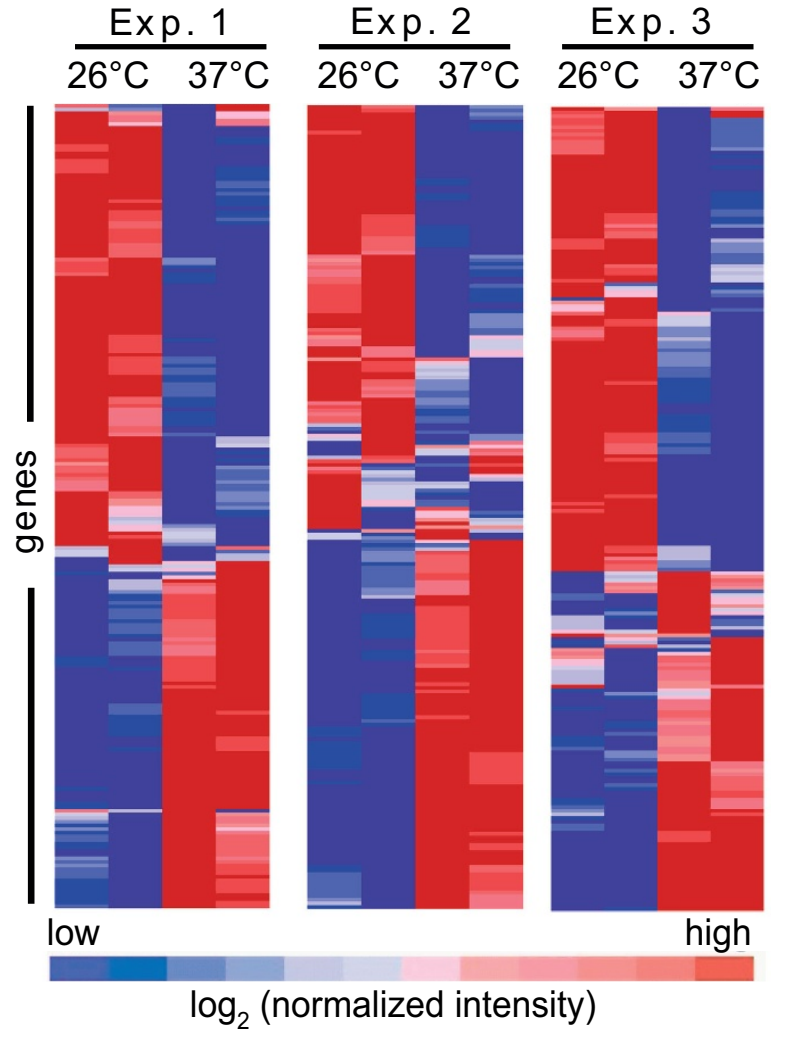

Figure I

Global Francisella gene expression changes induced by mammalian body temperature. Genes that were identified as statistically significant by $\mathrm{J} 5$ scores across three independent microarray experiments were subjected to hierarchical clustering. Fluorescence intensities were standardized by the minimum mean ratio array normalization followed by $\log _{2}$ transformation. Values were clustered using the Pearson correlation in GenePattern by independently inputting individual data from each experiment. Oligonucleotides testing individual LVS ORFs are in duplicate on each array and the results are displayed as two columns per experiment in GenePattern. The 95 induced genes and 125 repressed genes clustered together in this GenePattern output, validating the $\mathrm{J} 5$ statistical analysis from GEDA. (B).

expressed genes were analyzed, representing transcripts that were both significantly up- and down-regulated (Fig. $2 \mathrm{~A})$. Induced genes chosen for validation were the carbamoyl-phosphate synthase large chain, carB (FTL_0029), a hypothetical lipoprotein (FTL_1581), a dimethyladenosine transferase annotated to function in kasugamycin resistance, ksgA (FTL_1595), and phosphopentomutase, deoB (FTL_1664). The down-regulated genes tested by QPCR included two hypothetical proteins (FTL_1315 and FTL_1846), a cold shock protein, cspC (FTL_1361), and a
A.

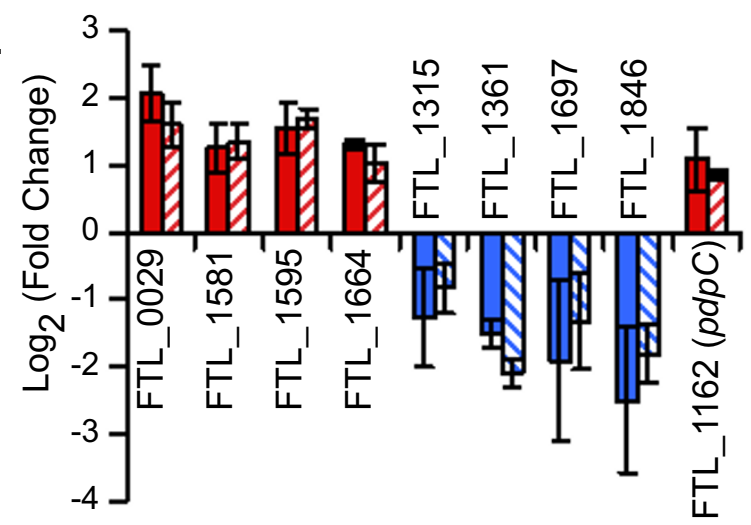

B.

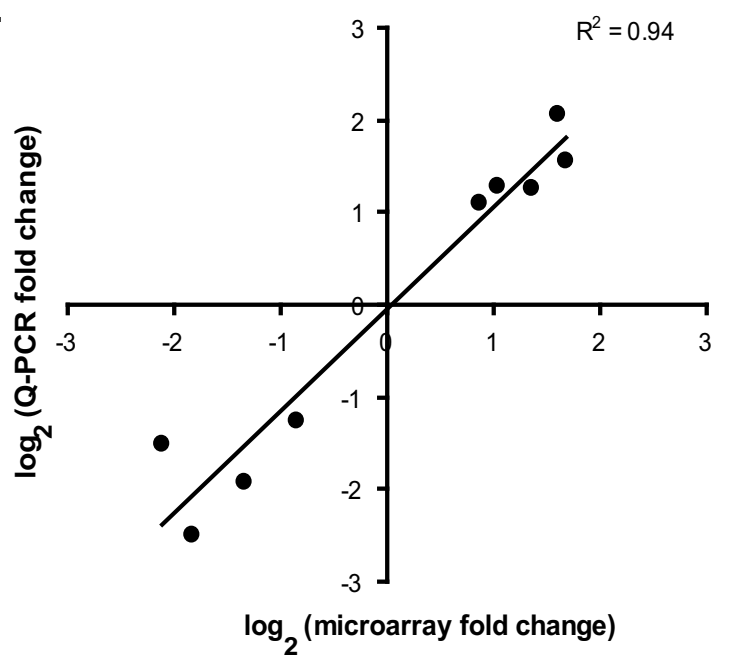

Figure 2

Validation of the microarray results and comparison with Q-PCR. (A) RNA from the microarray experiments depicted in panel A were tested for up- or down-regulation of specific genes using Q-PCR. Q-PCR data are represented with solid bars, whereas values from microarray experiments are depicted as striped bars. Both data sets are presented as mean \pm SEM from three individual experiments. (B) Correlation analysis of the microarray and Q-PCR transcript measurements for nine select $F$. tularensis LVS ORFs. The microarray $\log _{2}$ values were plotted against the Q-PCR $\log _{2}$ data. The correlation coefficient $\left(R^{2}\right)$ between the two analyses is 0.94 .

metal ion transporter, tyC (FTL_1697). A similar pattern of expression was observed in both Q-PCR and in the microarray experiments (Fig. 2A). A correlation plot (Fig. 2B) showed a strong, positive association between both data sets $\left(\mathrm{R}^{2}=0.94\right)$. This indicated the microarray platform and the subsequent statistical analysis were robust compared to the sensitive, though low-throughput Q-PCR approach. 
To analyze the differentially-regulated genes more thoroughly, we categorized their presumed protein products based on their Clusters of Orthologous Groups (COG) category. As expected, many of the induced and repressed genes were involved in central biological functions such as metabolism, transcription, translation, DNA replication, and RNA genes (Fig. 3). Heat shock proteins belong to the category labeled "posttranslational modification/ protein turnover/chaperones", and as anticipated, these genes were induced at the higher temperature, providing additional support to our microarray analysis (Fig. 3). The heat shock protein result was confirmed by analyzing Hsp70 protein quantity by Western blotting, which showed significantly more Hsp70 in bacteria shifted to $37^{\circ} \mathrm{C}$ versus $F$. tularensis LVS cultured at $26^{\circ} \mathrm{C}$ (data not shown). COG categories found only among the up-regulated transcripts included genes functioning in secretion and cell division, suggesting that host temperature may trigger these cellular processes and reflect, in part, enhanced growth rate (Fig. 3). In addition, the COG for bacterial defense mechanisms, which includes type I sitespecific restriction-modification systems, was uniquely down-regulated. This response may have evolved to allow this bacterium to better contend with environmental stresses, such as invading bacteriophages. We observed that a large percentage of both up- and down-regulated genes (44\% and 64\% respectively) did not belong to a known COG category (Fig. 3). Proteins with an unknown COG category may have a novel biological role in F. tularensis associated with their temperature regulation.

\section{F. tularensis LVS temperature regulation of genes necessary for infection}

We hypothesized that the shift from environmental to mammalian temperature may be used to regulate genes important for infection. Surprisingly, none of the genes encoded in the FPI were significantly up-regulated at $37^{\circ} \mathrm{C}$ in the microarray analysis. We also confirmed, by immunoblotting, that IglC protein levels were equivalent in bacteria grown at the two different temperatures (data not shown). Upon further scrutiny, we did notice that one gene in the FPI, $p d p C$ (FTL_0116; FTL_1162), was near the statistical threshold for induction at $37^{\circ} \mathrm{C}$. We therefore analyzed $p d p C$ transcript levels by Q-PCR as before, which

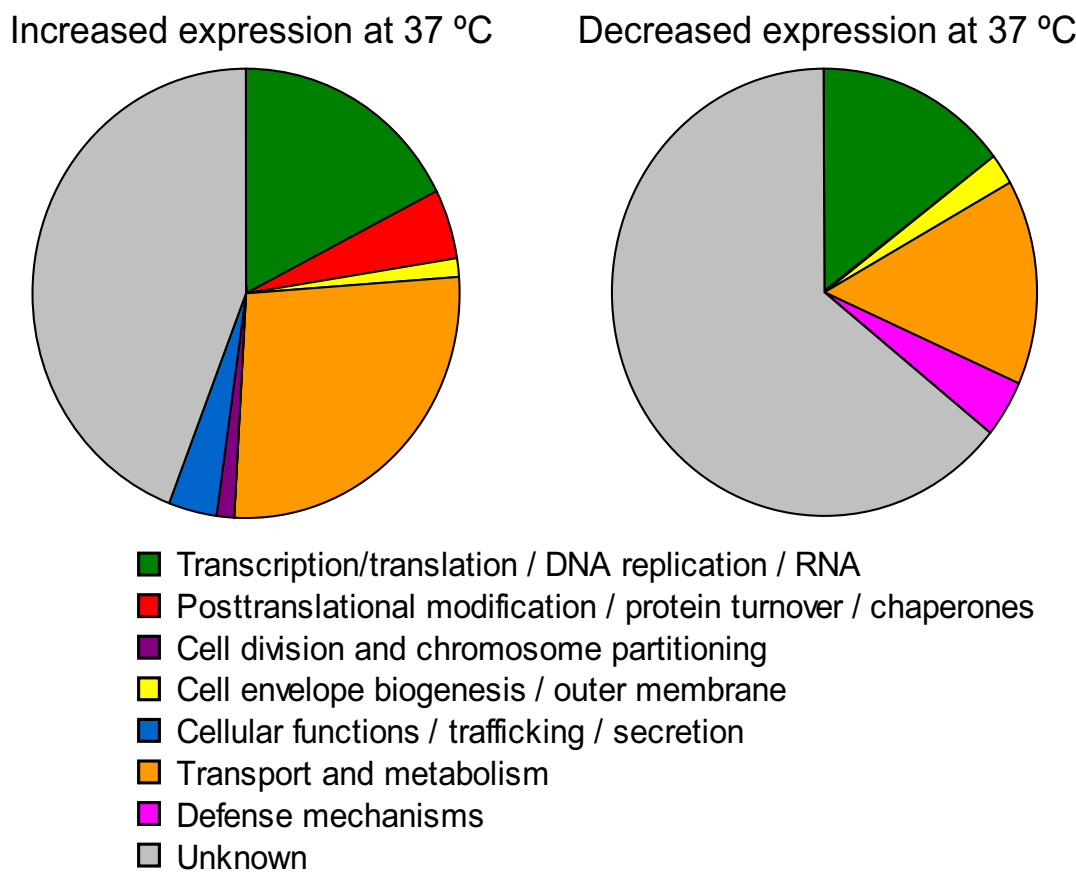

Figure 3

COG analysis of genes up- or down-regulated by mammalian temperature. COG categories were identified for each significantly up- or down-regulated gene based on the genomic annotation (accession, NC_07880). Specific COG categories were consolidated into general categories as follows: J, K, L, and RNA genes were combined into "Transcription/translation/DNA replication/RNA"; P, C, G, E, F, H, I, and Q were merged into "Transport and metabolism"; categories N and U were combined into "Cellular functions/trafficking/secretion"; and categories R, S, and uncategorized genes were classified as "Unknown". All other COG categories were reported as they were originally assigned. 
confirmed that this gene was induced at mammalian body temperature (Fig. 2A).

We next compared our list of genes induced at $37^{\circ} \mathrm{C}$ with those previously shown to be necessary for Francisella infection, or postulated to be involved in the pathogenesis of this organism (Table 2). Forty percent of the proteincoding genes significantly up-regulated at $37^{\circ} \mathrm{C}$ have been reported or predicted to be important for intracellular growth and/or virulence of $F$. tularensis (Table 2). The list depicted in Table 2 included an assortment of metabolic genes, chaperones, genes encoding hypothetical proteins, and others. The data from Table 2 and the $p d p C$ expression results in Fig. 2A further supported our hypothesis that genes important for Francisella infection are regulated by mammalian body temperature.

\section{FTL_I58I is associated with F. tularensis LVS virulence}

FTL_1581, annotated as a hypothetical lipoprotein, was induced by mammalian temperature more profoundly than any other hypothetical protein gene in the F. tularensis LVS genome (based on both fold change and J5 score; Additional file 1). We selected this gene for further study to test our hypothesis that temperature regulates genes necessary for infection. A BLAST search [32] against the National Center for Biotechnology Information database of non-redundant sequences did not identify proteins from organisms other than Francisella that had $>30 \%$ identity to FTL_1581 (data not shown). This suggested that FTL_1581 may have a function unique to F. tularensis. The primary structure of FTL_1581 was further examined by a PROSITE analysis [33] which indicated this protein likely contained a lipoprotein signal sequence (Fig. 4A) consistent with its annotation. This analysis also revealed that the signal sequence overlapped with a motif similar to that of the Enterobacterial TraT complement resistance protein (Fig. 4A). Although the initial BLAST search did not retrieve homologous proteins with high degrees of identity, it did show that FTL_1581 contained a domain with $20-24 \%$ identity and $40-44 \%$ similarity with the vacuolating cytotoxin (VacA; jhp0819) [34,35] and paralogs (jhp0556, jhp0856) of Helicobacter pylori J99 (Fig. 4A). Because FTL_1581 contained domains similar to other proteins that had a role in pathogenesis, we hypothesized that this protein may contribute to the virulence of F. tularensis.

Table 2: List of genes induced at $37^{\circ} \mathrm{C}$ shown or implicated to be associated with intracellular growth and/or virulence of $F$. tularensis.

\begin{tabular}{|c|c|c|c|}
\hline Locus tag & Description, gene name (if available) & Fold Change & Reference \\
\hline FTL_0028 & Aspartate carbamoyltransferase, pyrB & 2.2 & {$[12,14]$} \\
\hline FTL_0029 & Carbamoyl-phosphate synthase large chain, carB & 2.6 & {$[12,14,66]$} \\
\hline FTL_0030 & Carbamoyl-phosphate synthase small chain, carA & 2.6 & {$[12,14]$} \\
\hline FTL_0094 & Chaperone, $c l p B$ & 2.5 & {$[13,14,27,67,68]$} \\
\hline FTL_0198 & Pyridoxal/pyridoxine/pyridoxamine kinase, $p d x Y$ & 2.0 & [14] \\
\hline FTL_0267 & Chaperone Hsp90, htpG & 2.3 & {$[14,46,66,69]$} \\
\hline FTL_0307 & Dephospho-CoA kinase, coaE & & {$[46,69]$} \\
\hline FTL_0337 & Pseudogene with homology to miaB & 2.1 & {$[13]$} \\
\hline FTL_0445 & Hypothetical protein with homology to NADPH-dependent FMN reductase & 2.5 & {$[13,46,69]$} \\
\hline FTL_0479 & glycine cleavage system $\mathrm{P}$ protein, subunit I, qcvPI & 1.4 & [14] \\
\hline FTL_067I & Annotated as transcriptional regulator, homologous to Pantothenate kinase type III, coaX & 2.3 & {$[46,69]$} \\
\hline FTL_0672 & Aspartate-I-decarboxylase, panD & 2.0 & {$[14,46,69]$} \\
\hline FTL_0675 & Conserved hypothetical protein & 2.3 & {$[46,69]$} \\
\hline FTL_0837 & D-methionine binding transport protein, $\mathrm{ABC}$ transporter, membrane and periplasmic protein, met/Q & 2.0 & [13] \\
\hline FTL_0885 & PhoH-like protein & 1.9 & {$[14]$} \\
\hline FTL_0886 & Conserved hypothetical protein, yleA & 1.8 & [68] \\
\hline FTL_0899 & protease, GTP-binding subunit, $h f l X$ & 1.8 & [13] \\
\hline FTL_0928 & DJ-I/Pfpl family protein & 2.1 & [13] \\
\hline FTL_1048 & Conserved hypothetical protein & 1.8 & [14] \\
\hline FTL_II 190 & Chaperone protein (heat shock protein family 70 cofactor), grpE & 1.7 & {$[46,69]$} \\
\hline FTL_1338 & Alanine racemase, alr & 2.1 & [67] \\
\hline FTL_I474 & transcriptional elongation factor, qreA & 1.8 & [13] \\
\hline FTL_I 485 & Conserved hypothetical membrane protein & 2.2 & {$[46,69]$} \\
\hline FTL_I545 & SNO glutamine amidotransferase family protein & 2.6 & {$[46,69]$} \\
\hline FTL_I546 & Pyridoxine/pyridoxal 5-phosphate biosynthesis protein & 2.2 & {$[46,69]$} \\
\hline FTL_I 1553 & Succinyl-CoA synthetase beta chain, sucC & 1.6 & [13] \\
\hline FTL_I595 & Dimethyladenosine transferase, kasugamycin resistance, $k s g A$ & 3.2 & {$[14]$} \\
\hline FTL_I 664 & Phosphopentomutase, deoB & 2.1 & {$[14]$} \\
\hline FTL_I7I4 & Chaperonin (Hsp60 family), groEL & 3.2 & {$[14]$} \\
\hline FTL_I 1782 & adenine phosphoribosyltransferase, apt & 1.5 & {$[14]$} \\
\hline
\end{tabular}


A.

FTL_1581

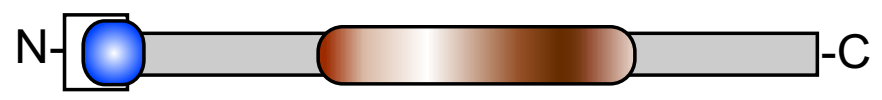

$\square$ Lipoprotein Signal Sequence

Enterobacterial Complement Resistance Domain, TraT

DVacA Domain, jhp0556, jhp0819, jhp0856

B.

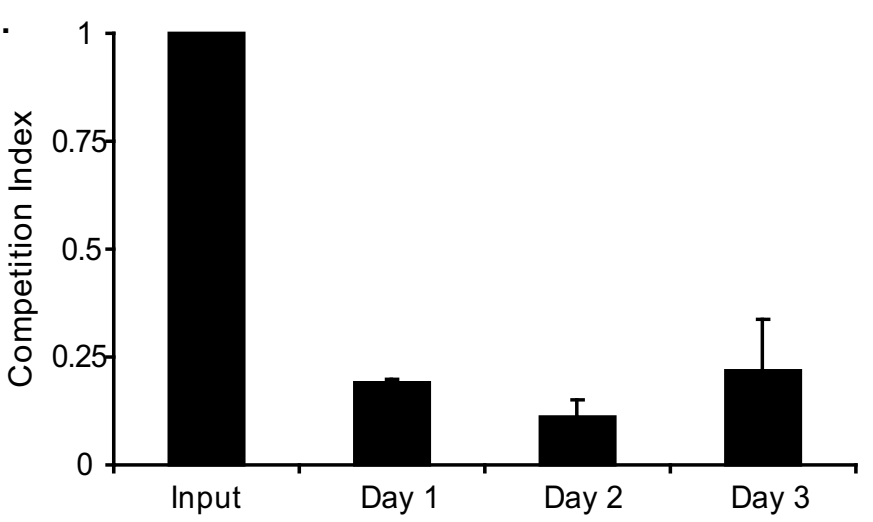

C.

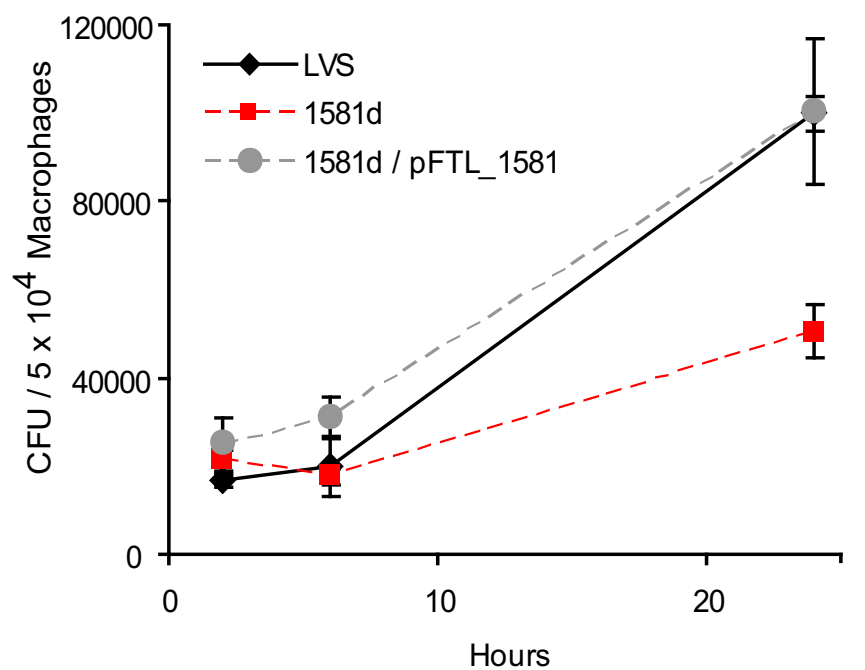

\section{Figure 4}

FTL_I58 I contributes to $F$. tularensis LVS virulence. (A) A schematic of FTL_I58I protein is depicted showing domains predicted by PROSITE. (B) Competition studies in the chicken embryo infection model using a mixture of LVS and I58Id (I:I based on $\mathrm{OD}_{600}$; viable bacteria in the inoculum were quantified by diluting and plating the input). Competition ratios (I58Id: LVS) were normalized to the input to account for differences in the inoculum. These ratios were analyzed for statistical significance by Chi square; $P<0.00$ I at days I, 2, and 3 post-infection. Data are mean competition ratio \pm SEM of three embryos per time point within one experiment and are representative of duplicate experiments. (C) Macrophages were infected with LVS, $158 \mathrm{Id}$, or $158 \mathrm{Id} / \mathrm{pFTL}$ I58I and were lysed at the indicated times. Data are mean \pm SEM of triplicate wells within one experiment and are representative of four experiments performed using cells from separate donors. Following log transformation, differences in CFU were determined by a Student's t-Test in which $P=0.003$ at $24 \mathrm{~h}$. 
We disrupted FTL_1581 in LVS, producing strain 1581d, to determine if this gene was associated with $F$. tularensis virulence. To assess the virulence of 1581d, we utilized a competition assay based on the chicken embryo infection model [36-38]. The chicken embryo produces a robust innate immune response comprised of complement, phagocytic cells, and cytokine production [39,40]. Here, chicken embryos were infected with a 1:1 mixture of LVS and $1581 \mathrm{~d}$. At days 1, 2, and 3 post-infection, wild-type LVS exhibited superior survival compared to $1581 \mathrm{~d}(P<$ 0.001 at each time point) (Fig. 4B). This result was not due to a growth defect since $1581 \mathrm{~d}$ grew identically to wild-type LVS when cultivated in bacterial growth medium (data not shown). In a separate experiment in which chicken embryos were infected only with 1581d, isolates from homogenates were all resistant to hygromycin, indicating that this mutant did not revert to wild type during infection (data not shown). Since 1581d was attenuated compared to LVS, the results suggest the function of the FTL_1581 gene product contributes to F. tularensis virulence.

We wanted to determine if the virulence attenuation of $1581 \mathrm{~d}$ in the chicken embryo infection model was due to a reduced ability to inactivate complement, as FTL_1581 contained a putative complement resistance domain (Fig. $4 \mathrm{~A})$. Therefore, we subjected LVS and $1581 \mathrm{~d}$ to serum sensitivity assays. There was equivalent survival of wild-type LVS and 1581d when cultured in media containing $20 \%$ serum or $20 \%$ heat-inactivated serum for up to $20 \mathrm{~h}$ (data not shown). To ensure that the serum complement was functional, E. coli DH5 $\alpha$ was used as a control. Here, the CFU from the serum-treated E. coli exhibited a reduction of 3 logs relative to the input or heat-inactivated serum groups after $30 \mathrm{~min}$ (data not shown). This suggested that the disruption in 1581d does not affect complement resistance.

We determined if FTL_1581 contributed to growth in a macrophage environment. Primary human monocytederived macrophages were infected in vitro with either LVS or $1581 \mathrm{~d}$. At various time-points, macrophages were lysed, and the lysates were diluted and plated to enumerate viable CFU. We observed attenuated growth of 1581d in macrophages at $24 \mathrm{~h}$ post-infection $(P=0.003)$ (Fig. 4C). When FTL_1581 was complemented in trans in 1581d, wild-type level of growth was restored (Fig. 4C). This complementation confirmed that the reduced intracellular fitness of 1581d was due to the inactivation of FTL_1581, and not due to polar effects or alternate mutations. This experiment (Fig. 4C) also suggested that the attenuation of $1581 \mathrm{~d}$ in the chicken embryo model (Fig. $4 \mathrm{~B})$ was likely due to a defect in intracellular survival. Together, the data presented here implicate FTL_1581, a Francisella ORF induced by mammalian body temperature that has no obvious homologs, with virulence and intracellular survival. Therefore, we propose that FTL_1581 be named temperature-induced, virulence-associated locus A, or tivA.

\section{Involvement of FTL_I664 (deoB) in uptake of F. tularensis LVS}

Many of the genes critical for Francisella infection involved metabolism (Table 2), a major COG category induced at $37^{\circ} \mathrm{C}$ (Fig. 3). This suggested that physiology vital for the success of $F$. tularensis as a pathogen was regulated by the temperature shift. Therefore, we were interested in determining the contribution of temperature-regulated metabolic genes toward Francisella pathogenesis. Previously, a microarray-based negative selection screen of $F$. novicida transposon mutants identified the phosphopentomutase, $\mathrm{deoB}$, as a gene contributing to growth and/or survival in mice [14]. In other bacteria, proteins encoded by $d e o B$ homologs normally catalyze the reversible reaction between ribose-1-phosphate and ribose-5-phosphate or between deoxyribose-1-phosphate and deoxyribose-5phosphate $[41,42]$. An F. tularensis LVS chromosomal disruption mutant of deoB, FTL_1664, was constructed (strain 1664d). This mutant had a cellular and colony morphology similar to its wild-type parent strain (data not shown). Also, 1664d grew similarly to wild-type LVS in bacterial culture medium (data not shown).

We employed the chicken embryo infection model [36$38]$ to confirm that $d e o B$ contributes to LVS pathogenesis, as it did in F. novicida [14]. Here, chicken embryos that had been infected with $F$. tularensis LVS 1664d exhibited significantly enhanced survival compared to those infected with wild-type LVS over a 5 day period $(P=$ 0.0254 ) (data not shown) corroborating the $d e o B$ data from F. novicida [14].

Accessing the host cytoplasm to replicate intracellularly is a hallmark of Francisella pathogenesis. Therefore, we next tested if the virulence attenuation of 1664d in the chicken embryo infection model was due to a defect in entering host cells. At two hours post-infection in vitro, human, monocyte-derived macrophages were treated with gentamicin to kill extracellular bacteria, followed by extensive washing. We consistently observed that substantially fewer $1664 \mathrm{~d}$ cells were phagocytosed relative to wild-type LVS (Fig. 5A) $(P=0.00005)$. Importantly, trans complementation of $1664 \mathrm{~d}\left(1664 \mathrm{~d} / \mathrm{pFTL} \_1664\right)$ rescued the uptake defect (Fig. 5A). This suggested $d e o B$ is involved in a bacterial mechanism that enhances uptake of $F$. tularensis. This finding was extended by conducting similar uptake assays in primary human dendritic cells (Fig. 5A). In both phagocytic cell types, the uptake defect of $1664 \mathrm{~d}$ was reproduced and complemented (Fig. 5A). 
A.
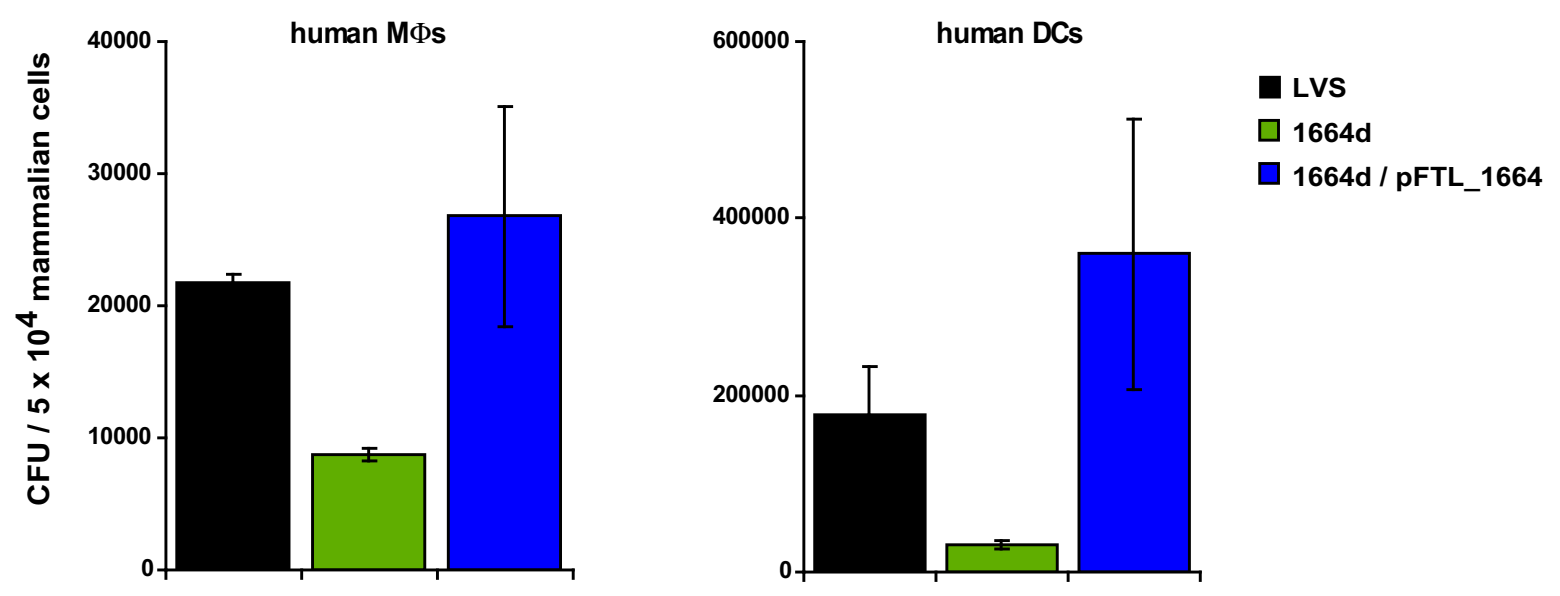

B.

LVS

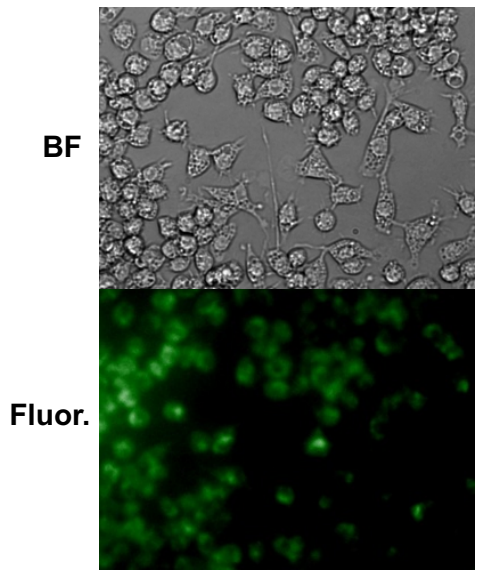

$1664 d$

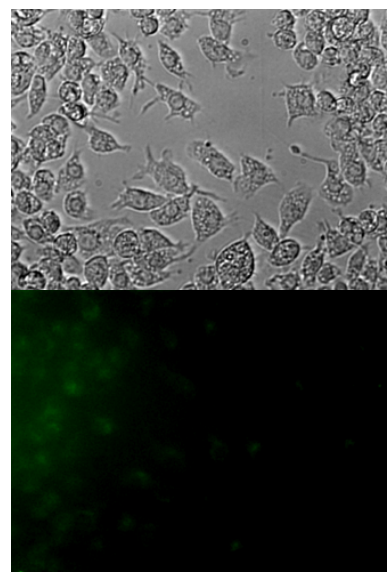

1664d / pFTL_1664

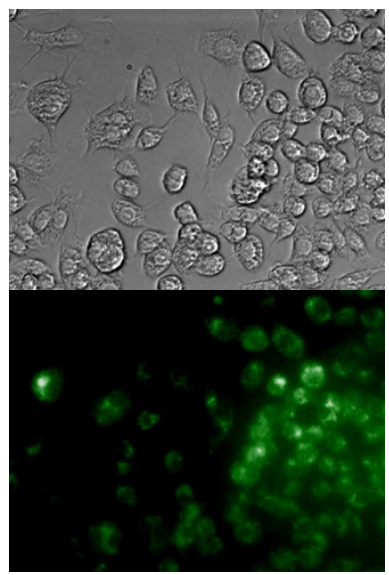

uninfected

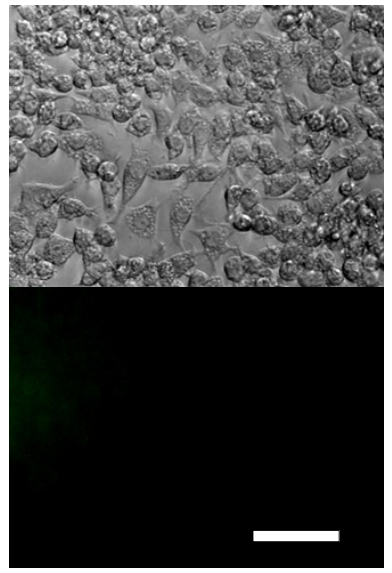

C.
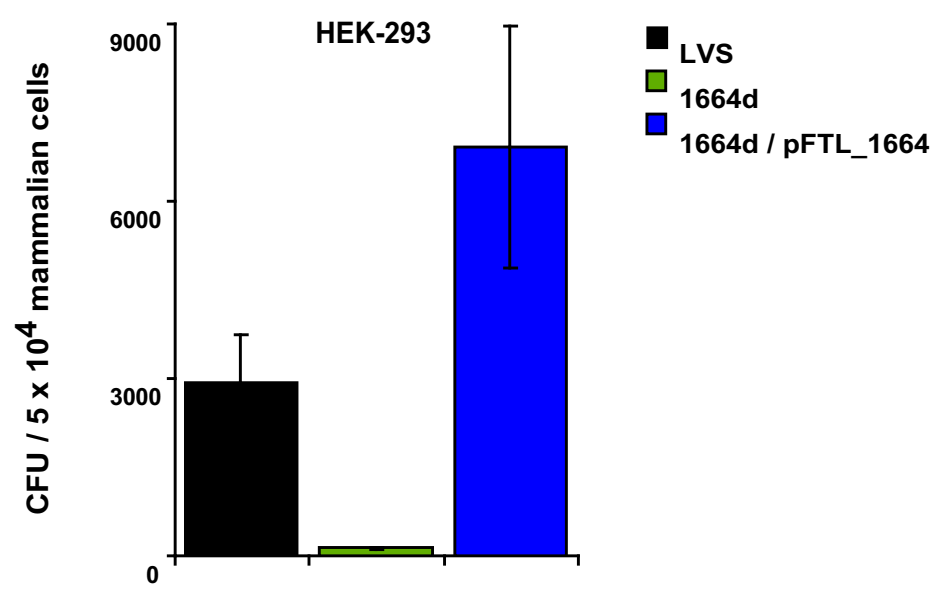

Figure 5 (see legend on next page) 
Figure 5 (see previous page)

deoB is important for entry of $\boldsymbol{F}$. tularensis LVS. (A) Primary human macrophages (MФs) or dendritic cells (DCs) were infected with either LVS, 1664d, or 1664d/pFTL_1664 in microtitre plates. After a two-hour incubation, wells were treated with gentamicin to kill extracellular bacteria, followed by vigorous washing. Subsequently, phagocytic cells were lysed and serial dilutions of lysates were plated for CFU enumeration. Data are mean \pm SEM of triplicate wells within one experiment and are representative of four (primary human macrophages) or two experiments (dendritic cells) performed using cells from separate donors. Following log transformation, differences in CFU between LVS and I664d were determined by a Student's t-Test in which $P=0.00005$ and 0.003 for MФs and DCs, respectively. (B) Bacteria were stained with the fluorescent green stain, Syto- 9 prior to infection. After a two-hour incubation with RAW 264.7 cells, extracellular bacteria were washed away and cells were analyzed under brightfield (BF) and fluorescence (Fluor.) microscopy. The exposure time was extended to enhance sensitivity of detecting the low numbers of 1664d within the RAW 264.7 cells, leading to some background fluorescence. Fluorescence images were initially captured in grayscale and pseudocolored using Adobe Photoshop. Data displayed are representative of duplicate experiments. Scale bar $=50 \mu \mathrm{m}$. (C) Human embryonic kidney 293 (HEK-293) cells were infected similarly to the phagocytic cells in panel A. Data are mean \pm SEM of triplicate wells within one experiment and are representative of three experiments. Following log transformation, differences in CFU between LVS and I664d were determined by a Student's t-Test in which $P=0.0004$.

We then qualitatively assessed uptake into phagocytes by microscopy to confirm the quantitative results obtained with CFU measurements. LVS, $1664 \mathrm{~d}$, and $1664 \mathrm{~d} /$ pFTL_1664 were treated with the green fluorescent stain, Syto-9, and then incubated with RAW 264.7 cells, a murine macrophage-like cell line. After a two hour incubation and washes, cells were observed by fluorescence microscopy. Here, RAW 264.7 cells infected with LVS or 1664d/pFTL_1664 exhibited bright green fluorescence (Fig. 5B). In contrast, the RAW 264.7 cells infected with 1664d produced considerably less fluorescence despite comparable inocula to the cultures (Fig. 5B). The results obtained by microscopy suggested the discrepancy in CFU between wildtype and $1664 \mathrm{~d}$ was not due to killing in the early phagosome. Rather, the levels of fluorescence in Fig. $5 \mathrm{~B}$ were consistent with the CFU uptake data presented in Fig. 5A and confirmed that the temperature-regulated $d e o B$ is important for optimal uptake by mammalian phagocytes.

To determine if $d e o B$ contributed to entry into non-phagocytic cells, we exposed the human embryonic kidney cell line HEK-293 to either LVS, 1664d, or 1664d/pFTL_1664. At two hours post-infection, these cells were treated with gentamicin to kill extracellular bacteria followed by extensive washing. Subsequently, HEK-293 cells were lysed and the lysates were diluted and plated to enumerate CFU. Here we observed that $1664 \mathrm{~d}$ showed reduced entry into the non-phagocytic HEK-293 cells (Fig. 5C). The uptake defect was again rescued by trans complementation (Fig. $5 \mathrm{C}$ ). These data suggest that $d e o B$ contributes significantly to entry into both phagocytic (Fig. 5A and 5B) and nonphagocytic cells (Fig. 5C).

\section{Discussion}

In this paper, we provide evidence that $F$. tularensis LVS undergoes significant gene expression changes in response to mammalian body temperature (Fig. 1 and 2, Table 2, and Additional files 1 and 2). We hypothesized that genes important for infection of mammals may be induced during transition to this higher temperature. Although some genes, such as ribosomal RNA and tRNA genes, may reflect an increased growth rate at $37^{\circ} \mathrm{C}$, our overall hypothesis was supported by the finding that $40 \%$ of the protein coding genes induced at $37^{\circ} \mathrm{C}$ have been shown or implicated to be important for successful Francisella infection (Table 2). In addition, we showed that two specific genes induced at $37^{\circ} \mathrm{C}$ contribute to the fitness of $F$. tularensis LVS during infection. While infection of a mammalian host exerts a complex set of signals on $F$. tularensis in addition to temperature, it is likely that many of the unexplored genes induced at mammalian temperature have a role in pathogenesis of $F$. tularensis. Differential responses to temperature among virulent and less virulent $F$. tularensis strains will also provide a focused list of relevant candidate virulence determinants to investigate further. The products of temperature-regulated genes with central roles in physiology and virulence could be targets for novel therapeutics or mutation to generate defined live attenuated vaccines.

One gene induced at $37^{\circ} \mathrm{C}$, tivA (FTL_1581), encodes a protein with little overall identity to other proteins. It does, however, contain regions of meager similarity to the domains of proteins involved in the pathogenesis of other bacteria (Fig. 4A). We showed that this gene was necessary for full $F$. tularensis LVS virulence in the chicken embryo model, most likely because it contributed to optimal replication in primary human macrophages (Fig. 4B and 4C). In a previous high-throughput microarray-based, negative-selection screen for $F$. novicida genes important for a murine infection, the tivA allele of F. novicida (FTN_0573) was not identified [14]. There are two possible explanations for this discrepancy. There may be intrinsic differ- 
ences between $F$. tularensis LVS and F. novicida pathogenesis [43] and their reliance on tivA. A more probable explanation is that F. tularensis LVS and the more pathogenic F. tularensis Schu S4 contain a single copy of this gene. In contrast, F. novicida has two homologs of tivA in its genome, suggesting the possibility of functional redundancy. These alternate forms (FTN_1103, 52\% identity; FTN_1101,49\% identity) may have compensated for a mutation of tivA (FTN_0573) during the negative-selection screen [14], thereby masking any effects on pathogenesis. This possibility underscores the value of analyzing several different strains when probing F. tularensis pathogenesis.

Strain $1664 \mathrm{~d}$, a disruption mutant of $d e o B$, exhibited significant reduction in uptake into mammalian cells (Fig. 5) indicating that this gene's product is involved in a mechanism that enhances entry. It would be advantageous for Francisella to couple expression of a gene important for uptake $(d e o B)$ with mammalian temperature, a cue encountered early in infection. Augmenting entry would improve access to the intracellular environment in which F. tularensis proliferates [44]. A previous study showed that pyrB (FTT1665) from F. tularensis Schu S4 was important for invasion in the human HepG2 hepatocellular carcinoma line [12]. However, a Schu S4 mutant of pyrB was not defective in uptake by J774.1 macrophage-like cells [12], suggesting that the Francisella mechanisms of optimal uptake by phagocytes and invasion into hepatocytes are separate phenomena. In another prior study, mutants of MglA, a key regulator of the FPI [45], and mutants of six genes controlled by this protein were not defective for cell entry [46]. This suggests that Francisella has evolved separate regulatory mechanisms for enhancing uptake and for intracellular survival. However, based on our data, genes critical for both phenomena are affected by mammalian temperature indicating that this cue is an important signal for multiple regulatory networks in Francisella. The uptake defect we have shown with the $d e o B$ mutant in both phagocytic and non-phagocytic cells has not been described previously.

In our system, DeoB may have a direct or indirect role in the uptake of Francisella. DeoB may influence the LPS structure of Francisella, secondarily improving interactions with host cell receptors. Importantly, complement receptors and mannose receptors are crucial for optimal Francisella phagocytosis [47-50]. This model is consistent with the fact that $d e o B$ is induced at $37^{\circ} \mathrm{C}$ and the finding that Francisella LPS structure is different at lower temperature versus mammalian temperature $[29,30]$. Alternatively, DeoB may directly promote Francisella entry into host cells as this protein may have an additional function aside from being a phosphopentomutase. Another possibility is that mutation of metabolic genes in pathogenic bacteria can yield pleiotropic effects, resulting in defects in virulence mechanisms, including invasion [12]. Further investigation is necessary to determine the precise mechanism of Francisella DeoB in host cell entry.

The data presented here suggest that some genes important for Francisella during infection are induced by mammalian temperature. Although we showed by Q-PCR that $p d p C$ transcripts were induced at $37^{\circ} \mathrm{C}$, none of the other loci in the FPI [6] were up-regulated at mammalian body temperature. This is consistent with other findings suggesting that IglC protein levels were not induced by a shift from $37^{\circ} \mathrm{C}$ to $42^{\circ} \mathrm{C}$ [7]. Because many of the loci in the FPI are essential for intra-amoeba growth [45], which would occur at lower, ambient temperatures, it seems logical that these genes are not regulated by temperature. Therefore, the virulence associated-genes induced by mammalian temperature that we have identified are on a separate regulon than most of the genes of the FPI. This suggests Francisella possesses an intricate regulatory circuit to maximize its success in diverse environments.

\section{Conclusion}

F. tularensis LVS undergoes significant gene expression changes in response to mammalian temperature. This temperature shift is important for the regulation of pathogenesis. Our study characterizes a previously underappreciated environmental cue that regulates the expression of F. tularensis genes associated with virulence in other studies. Importantly, the collection of temperature-regulated genes also defines a rich set of novel candidate virulence determinants, including tivA (FTL_1581). Detailed investigation of tivA and $d e o B$ (FTL_1664) revealed unknown or unrecognized roles of these genes in intracellular survival and entry into mammalian cells, respectively.

\section{Methods}

\section{Bacterial strains and growth conditions}

Bacterial strains used in this study can be found in Table 1. All broth cultures were grown with agitation (250 rpm). For general cultivation of Escherichia coli, bacteria were grown at $37^{\circ} \mathrm{C}$ on LB agar plates, or in LB broth. F. tularensis LVS, a model organism for tularaemia, was used in this study. For F. tularensis LVS strains, frozen stock cultures were streaked onto chocolate II agar plates and incubated at $37^{\circ} \mathrm{C}, 5 \% \mathrm{CO}_{2}$ for $2-4$ days. These bacteria were subsequently used to inoculate broth cultures. For experiments assessing the effect of temperature on transcript levels, Chamberlain's chemically defined broth medium (CDM) [51] was inoculated with LVS and incubated at $37^{\circ} \mathrm{C}$ overnight. This start-up culture was used to inoculate fresh CDM ( $2 \mathrm{ml}$ start-up culture into $25 \mathrm{ml}$ fresh broth) and incubated at $26^{\circ} \mathrm{C}$ for $24 \mathrm{~h}$. Following this incubation, the optical density $\left(\mathrm{OD}_{600}\right)$ of this culture was recorded and RNA was extracted. For the temperature 
shift, $5 \mathrm{ml}$ of the same culture was diluted into $25 \mathrm{ml}$ fresh $\mathrm{CDM}$ and incubated at $37^{\circ} \mathrm{C}$ until attaining an $\mathrm{OD}_{600}$ comparable to the $26^{\circ} \mathrm{C}$ culture (typically $\sim 6 \mathrm{~h}$ ). When the $37^{\circ} \mathrm{C}$ culture reached the desired $\mathrm{OD}_{600}$, RNA was harvested. This strategy of growing bacteria to comparable $\mathrm{OD}_{600}$ prior to RNA extraction was similar to a previous study assessing global temperature regulation in Group A Streptococcus [19] and mitigates the effects of growth phase on the subsequent analysis.

For macrophage and chicken embryo infections, LVS strains were grown in TSBc (trypticase soy broth [Becton, Dickinson and Company] supplemented with $0.1 \%$ Lcysteine hydrochloride monohydrate) at $37^{\circ} \mathrm{C}$ while shaking at $250 \mathrm{rpm}$. When required, antibiotics were added to the media at the following concentrations: ampicillin at $150 \mu \mathrm{g} / \mathrm{ml}$ for E. coli; kanamycin at $35 \mu \mathrm{g} / \mathrm{ml}$ for E. coli and $10 \mu \mathrm{g} / \mathrm{ml}$ for F. tularensis LVS; chloramphenicol at $5 \mu \mathrm{g} / \mathrm{ml}$ for F. tularensis LVS; polymixin at $100 \mu \mathrm{g} / \mathrm{ml}$; and hygromycin at $200 \mu \mathrm{g} / \mathrm{ml}$.

The rationale for using CDM for the transcriptional analysis, while TSBc was used for all other experiments is twofold. Using CDM for general cultivation of LVS is not practical because CDM is an aqueous mixture of 22 nutrients, some of which do not have a long shelf-life. Secondly, CDM was selected for transcriptional analyses to benefit future studies to analyze synergistic effects of temperature and media components.

\section{RNA extraction}

Immediately upon removal from the shaking incubator, six ml of broth culture were mixed with $18 \mathrm{ml}$ TriReagent LS (Molecular Research Center). Chloroform $(4.8 \mathrm{ml})$ was added to this material, and the aqueous phase was subsequently separated by centrifugation in a Phase Lock Heavy tube (Eppendorf). RNA was precipitated from this aqueous layer with isopropanol, followed by centrifugation. Pelleted material was washed in $80 \%$ ethanol and resuspended in nuclease-free water. This RNA-containing mixture was treated with DNase (Turbo DNA-free, Ambion), and then precipitated using ammonium acetate and ethanol. RNA quantity was measured spectrophotometrically, and quality was assessed using an Agilent Bioanalyzer.

\section{Microarray analysis}

Custom Agilent Francisella microarrays designed using the eArray framework were used in this study. All predicted open reading frames, including pseudogenes, were included for F. tularensis subsp. holarctica LVS, F. tularensis subsp. tularensis (SchuS4), F. tularensis subsp. holarctica OSU18, F. novicida U112 and the Francisella plasmids, pOM1, and pFNL10. Individual genes from LVS, SchuS4, and OSU18 were spotted in duplicate on this array, whereas genes from the other strains and plasmids were printed as single copies. CDNA was synthesized from RNA by reactions using random hexamers (Invitrogen) and MMLV (Agilent). The cDNA target was labelled with Alexa Fluor 555 conjugated dUTP according to manufacturer's protocol (AF555-aha-dUTP; Invitrogen). Labelling reactions were incubated at $40^{\circ} \mathrm{C}$ for 3 hours. After cDNA synthesis, RNA was hydrolyzed with with $\mathrm{NaOH}$ and EDTA, and subsequently, the $\mathrm{pH}$ was neutralized with an equivalent volume of $\mathrm{HCl}$. The labelled cDNA was precipitated using isopropanol and ammonium acetate and washed with $80 \%$ ethanol. $0.5 \mu \mathrm{g}$ of labelled cDNA was hybridized to custom Agilent $8 \times 15 \mathrm{~K}$ microarrays according to the protocol of the manufacturer and incubated at $60^{\circ} \mathrm{C}$ for 18 hours in a rotary oven. Following hybridization, arrays were washed with Agilent wash buffers before being scanned on an Agilent microarray scanner. At least 3 separate RNA extractions were used for each condition tested by microarray $\left(26^{\circ} \mathrm{C}\right.$ or $37^{\circ} \mathrm{C}$-grown bacteria).

Gene Expression Data Analyzer (GEDA; http://bioinfor matics.upmc.edu/GE2/GEDA.html) was utilized for analysis of the microarray data [31]. This online software package was used for minimum mean ratio array normalization followed by $\log _{2}$ transformation. Data were grouped into two categories, cultivated at $26^{\circ} \mathrm{C}$ and shifted to $37^{\circ} \mathrm{C}$, and analyzed for significance with the $\mathrm{J} 5$ statistical test [31]. The J5 metric was designed for data sets composed of limited replicates, thereby reducing the chance of generating false positives [31]. Genes were considered to be significantly differentially regulated if they had a J5 score greater than 2 . Additional files 1 and 2 consist of lists showing both the J5 value and fold change for genes that were significantly up- or down-regulated upon a shift to mammalian temperature. Normalized, $\log _{2}$ transformed intensity values for genes that were differentially expressed were input into GenePattern [52] and data are presented after hierarchical clustering (Pearson correlation).

Categories assigned for clusters of orthologous groups were identified for each significantly up- or down-regulated gene based on the annotation assigned from the $F$. tularensis holarctica genome (accession, NC_07880). Specific clusters of orthologous groups categories were consolidated into general categories as follows: J, K, L, and RNA genes were combined into "Transcription/translation/DNA replication/RNA"; P, C, G, E, F, H, I, and Q were merged into "Transport and metabolism"; categories $\mathrm{N}$ and $U$ were combined into "Cellular functions/trafficking/secretion"; and categories R, S, and uncategorized genes were classified as "Unknown". All other clusters of orthologous groups categories were reported as they were originally assigned. 


\section{Quantitative real time PCR}

One $\mu \mathrm{g}$ of total RNA was used as a template for cDNA synthesis catalyzed by Superscript III (Invitrogen). Diluted cDNA was used as a template for real time reactions containing primer sets (designed by Primer 3 [53] for the desired genes) and SYBR Green Supermix (BioRad). These reactions were carried out on a BioRad IQ5 real time machine. The bacterial 50S ribosomal protein L24 (FTL_0247) was used as an internal reference, as it was observed to have no change in expression following a shift to $37^{\circ} \mathrm{C}$ according to the microarray analysis (data not shown). The quantitative real time PCR data are presented as $\log _{2}$ transformed fold change values $\left(37^{\circ} \mathrm{C}\right.$ versus $\left.26^{\circ} \mathrm{C}\right)$.

\section{Construction of plasmids}

Plasmids and primers used in this study can be found in Table 1. The disruption plasmids, pMQ131hyg1581d and pMQ131hyg1664d were constructed using the following procedures. First, the PvuI/SpeI fragment of pMP615 containing $h y g$ under the control of the groEL promoter was subcloned into pMQ131 (R. Shanks and G. O'Toole, unpublished data) that had been digested with PvuI/XbaI which produced pMQ131hyg. The internal 560 base pairs of FTL_1581 were amplified by PCR using the primers 1581_560F and 1581_560R and this amplicon was initially TA cloned into pGEM-T (Promega). The KpnI/ BamHI fragment of this construct containing the internal portion of FTL_1581 was subcloned into pMQ131hyg that had been digested with these same enzymes, which produced pMQ131hyg1581d. Similarly, the internal 900 base pairs of FTL_1664 were amplified by PCR using the primers 1664_900F and 1664_900R and this amplicon was initially TA-cloned into pGEM-T (Promega). Subsequently, this fragment internal to FLT_1664 was subcloned (KpnI/BamHI) into pMQ131hyg, producing the plasmid pMQ131hyg1664d.

The FTL_1581 complementing plasmid (pFTL_1581) was constructed using the following procedures. The primers 1581_clone_up and 1581_clone_down were used to amplify 600 base pairs upstream, the entire FTL_1581 open reading frame, and 100 base pairs downstream of this gene by PCR. This amplicon encompassed the predicted native FTL_1581 promoter, this gene's coding region, as well as the predicted transcriptional stop (data not shown). Initially, this amplicon was TA-cloned into pGEM-T (Promega). The SacI/SacII fragment of this construct containing FTL_1581 was subsequently subcloned into pMQ2 (R. Shanks and G. O'Toole, unpublished data) that had been digested with these same enzymes. This yielded pFTL_1581.

The FTL_1664 (deoB) complementing plasmid (pFTL_1664) was constructed using the following proce- dures. Initially, the Kan ${ }^{\mathrm{R}}$ gene from pFNLTP8 was deleted using an inverse PCR strategy [54]. The primers F8AgeI and F8XhoI were used to amplify pFNLTP8. Following PCR, template DNA was digested with DpnI leaving only amplified product. This amplicon was self-ligated, producing pF8AX. The cat194 gene was amplified by PCR using the primers XhoICAT and AgeICAT with pMQ2 as a template, and this amplicon was TA-cloned into pGEM-T (Promega). The Age I/XhoI fragment of this construct that encoded the cat194 gene was subcloned into pF8AX using these same enzymes producing pF8CAT. 1664_clone_up and 1664_clone_down were used to amplify 600 base pairs upstream, the entire FTL_1664 open reading frame, and 100 base pairs downstream of this gene by PCR. This amplicon encompassed the predicted native FTL_1664 promoter, this gene's coding region, as well as the predicted transcriptional stop (data not shown). Initially, this amplicon was TA-cloned into pGEM-T(Promega). The BamHI/KpnI fragment of this construct containing FTL_1664 was subsequently subcloned into pF8CAT that had been digested with these same enzymes. This yielded pFTL_1664.

\section{Construction of the FTL_I664 and FTL_I 58 I mutants}

F. Otularensis LVS disruption mutants of FTL_1664 and FTL_1581 were constructed as previously reported [55]. A homologous recombination between the LVS chromosomal copy of FTL_1581 and the internal FTL_1581 fragment in pMQ131hyg1581d would disrupt the coding sequence of 38 amino acids at the C-terminus. Also, homologous recombination between chromosomal FTL_1664 and pMQ131hyg1664d would disrupt coding sequence for the C-terminal 56 amino acids of the encoded protein. Disruption constructs (either pMQ131hyg1664d or pMQ131hyg1581d) were mobilized into F. tularensis LVS by triparental mating. Mating mixes were composed of LVS ( $\left.10^{9} \mathrm{CFU}\right)$, E. coli/pRK2013 ( $\left.10^{7} \mathrm{CFU}\right)$, and either E. coli/pMQ131hyg1664d or E. coli/ pMQ131hyg1581d (107 CFU). Similarly to the previously described Francisella conjugation methodology [56], the mating mixture here was plated on LB agar plates, and incubated at room temperature for 18 hours. Cells were resuspended in phosphate buffered saline (PBS) and spread onto chocolate II agar plates containing polymyxin $(100 \mu \mathrm{g} / \mathrm{ml})$ and hygromycin. Hygromycin-resistant colonies were screened by PCR using primers specific for either FTL_1581 or FTL_1664 and the vector-portion of pMQ131hyg1581d or pMQ131hyg1664d. The F. tularensis LVS FTL_1664 and FTL_1581 disruption mutants (FTL_1664::pMQ131hyg1664d;

FTL_1581::pMQ131hyg1581d) are referred to as strains $1664 \mathrm{~d}$ and $1581 \mathrm{~d}$ respectively. Mobilization of complementation constructs into the disruption mutants was accomplished by electroporation as previously described [57]. 


\section{Complement resistance assay}

Bacteria $\left(1.5 \times 10^{9} \mathrm{CFU}\right)$ were incubated in solutions of PBS with 20\% serum (human serum [Gemini Bioscience]) or $20 \%$ heat-inactivated serum at $37^{\circ} \mathrm{C}$ while shaking at $250 \mathrm{rpm}$. Serum was incubated at $56^{\circ} \mathrm{C}$ for 30 minutes to inactivate complement. At certain time-points, cell suspensions were diluted and plated to enumerate CFU.

\section{Chicken embryo infections}

Chicken embryos were infected with F. tularensis LVS, $1664 d$, and $1581 d$ as previously described $[37,38]$. Whiteleghorn chicken eggs (fertilized, specific pathogen free) were purchased from Charles River Laboratories, North Franklin, CT, USA. Eggs were incubated at $37^{\circ} \mathrm{C}$ with gentle rocking and humidity for one week prior to infection. Following the initial 7 day incubation, those without a live embryo were discarded. For infections, the surface of the egg shell was sterilized with $70 \%$ ethanol. The egg shell membrane was exposed and removed after introducing a small hole in the shell. Bacteria suspended in PBS $(100 \mu \mathrm{l})$ were then injected beneath the chorioallantoic membrane. The hole in the egg shell was covered with transparent tape and subsequently eggs were incubated as previously described. On a daily basis, eggs were candled to assess viability for 6 days. As previously reported [37], embryos that expired within $24 \mathrm{~h}$ of the infection were presumed to have experienced lethal trauma during inoculation, and were removed from the experiment. Survival differences in chicken embryo infections were analyzed with the log rank test in GraphPad Prism 5.

Competition studies in the chicken embryo infection model were conducted similar to the single infections described above. Here chicken embryos were infected with a mixture of LVS and 1581d (1:1 based on $\mathrm{OD}_{600}$ $\sim 10^{5}$ total bacteria). Actual input ( $6.5 \times 10^{5}$ total bacteria) was determined by diluting the inoculum followed by plating to enumerate viable bacteria. Three infected, viable eggs were sacrificed at 1, 2, and 3 days (9 total eggs) post infection. Egg contents were homogenized with an OMNI tissue homogenizer, and serial dilutions of the homogenates were plated on chocolate II agar plates with or without antibiotic. The total number of 1581d (plates with antibiotic) was subtracted from the number of total bacteria (plates without antibiotic) to determine the amount of viable wild-type LVS. Competition ratios (1581d: LVS) were normalized to the input to account for small differences in the inocula, as has been done previously $[58,59]$. Competition ratios were analyzed for statistical significance by Chi square.

\section{Mammalian cell infections}

Human monocytes were differentiated into macrophages by in vitro culture as has been described previously $[11,57,60]$. Buffy coats from blood donations (Central Blood Bank, Pittsburgh, Pennsylvania) served as the source of monocytes. Monocytes were purified using Ficoll gradients (Amersham Biosciences) to isolate PBMCs, Optiprep gradients (Axis-Shield) to enrich for monocytes, and panning on plastic to further purify monocytes (final purity $>95 \%$ based on microscopy). Cells were cultured in $60 \mathrm{~mm}$ culture dishes for 7 days at $37^{\circ} \mathrm{C}$ with $5 \% \mathrm{CO}_{2}$ in $7 \mathrm{ml}$ of DMEM (Invitrogen) supplemented with 20\% FCS (Invitrogen), 10\% human serum (Gemini Biosciences), $25 \mathrm{mM}$ HEPES (Gibco), and 1\% Glutamax (Invitrogen) [11,57,60]. Macrophages were detached from the culture dish on day 7 using a lidocaine/ EDTA solution ( $5 \mathrm{mM}$ EDTA and $4 \mathrm{mg} / \mathrm{ml}$ lidocaine in PBS pH 7.2). For monocyte-derived dendritic cells, human monocytes were seeded at a density of $1 \times 10^{6}$ cells $/ \mathrm{ml}$ in 24 well plates (Costar) in complete RPMI [ $10 \%$ FCS, $25 \mathrm{mM}$ HEPES, 1\% non-essential amino acids, 1\% sodium pyruvate, $1 \%$ Glutamax and $0.1 \%$ 2-mercaptoethanol (all from Gibco)] supplemented with $1000 \mathrm{U} / \mathrm{ml}$ GM-CSF and $1000 \mathrm{U} / \mathrm{ml} \mathrm{IL-4} \mathrm{(both} \mathrm{from} \mathrm{eBioscience)} \mathrm{and}$ incubated at $37^{\circ} \mathrm{C}$ with $5 \% \mathrm{CO}_{2}$. On day 3 of culture, $10 \%$ of the media was replaced with fresh complete RPMI supplemented with GM-CSF and IL-4 and non-adherent cells were harvested at day 5 . For in vitro infections, all primary cells were washed and resuspended in DMEM supplemented with 1\% human serum, $25 \mathrm{mM}$ HEPES, and 1\% Glutamax and then plated onto Primaria-coated 96well culture dishes (Becton, Dickinson and Company) at a density of $5.0 \times 10^{4}$ cells per well.

Murine macrophage-like RAW 264.7 cells (ATCC number TIB-71) were routinely cultured in DMEM supplemented with $10 \%$ fetal calf serum, $25 \mathrm{mM} \mathrm{HEPES}$, and $1 \%$ Glutamax with $100 \mathrm{U} / \mathrm{ml}$ penicillin-streptomycin. Two days prior to infection, the medium for these cells was replaced with DMEM supplemented with 10\% human serum, $25 \mathrm{mM}$ HEPES, and 1\% Glutamax, and infections were carried out using this same medium.

HEK-293 cells (ATCC number CRL-1573), a non-phagocytic cell line [61], were cultivated in DMEM supplemented with $10 \%$ fetal calf serum, $25 \mathrm{mM} \mathrm{HEPES}$, and $1 \%$ Glutamax with $100 \mathrm{U} / \mathrm{ml}$ penicillin-streptomycin. One day prior to infection, HEK-293 cells were seeded in 96well plates at a concentration of $5 \times 10^{4}$ cells per well in this same medium devoid of antibiotic and infections were carried out in this same medium.

For infection experiments, bacterial cultures were adjusted to an $\mathrm{OD}_{600}$ of 0.3 (approximately $1.5 \times 10^{9} \mathrm{CFU} / \mathrm{ml}$ ) and diluted to attain a multiplicity of infection (MOI) of 500, 
which typically yields infection rate $>80 \%$ after a 2 hour co-incubation $[11,62]$. Alternatively, macrophages were suspended in DMEM supplemented with $10 \%$ human serum, $25 \mathrm{mM}$ HEPES, and 1\% Glutamax and transferred to culture dishes before infection. Prior to administration of the bacteria onto the macrophages, the $F$. tularensis strains were incubated at $37^{\circ} \mathrm{C}$ with $5 \% \mathrm{CO}_{2}$ for $20 \mathrm{~min}$ in this same medium. Macrophages were infected with bacteria that had been diluted to an MOI of 40 . This alternative infection protocol used a lower MOI because it took advantage of the complement-mediated uptake of $F$. tularensis into macrophages [47]. Comparable results were obtained regardless of which infection protocol was used. Actual MOIs were measured by plating serial dilutions of inocula on chocolate II agar plates.

For intracellular CFU enumeration, mammalian cells were exposed to the initial bacterial load for 2 hours at $37^{\circ} \mathrm{C}$ with $5 \% \mathrm{CO}_{2}$ and then incubated with gentamicin $(20 \mu \mathrm{g} / \mathrm{ml})$ for $20 \mathrm{~min}$ to kill extracellular bacteria. The cells were washed with warm Hank's balanced salt solution and then incubated at $37^{\circ} \mathrm{C}$ with $5 \% \mathrm{CO}_{2}$ for another 22-48 h with fresh culture media. At the indicated timepoints post-infection, mammalian cells were lysed with $0.02 \%$ sodium dodecyl sulfate. The 2 hour time point was used to determine entry similarly to a prior study [46]. Serial dilutions of the lysates were plated on chocolate II agar plates for enumeration of viable bacteria. CFU counts were converted to $\log _{10}$ values and analyzed by the Student's t-Test to determine statistical differences. For uptake analysis, CFU were normalized to actual MOI to account for minor variations in the density of inocula [46].

For fluorescence microscopy, bacteria were stained with $10 \mu \mathrm{M}$ Syto 9 (Invitrogen) for $15 \mathrm{~min}$ and washed three times with PBS prior to infection. Here, stained cells were diluted in DMEM supplemented with 10\% human serum, $25 \mathrm{mM}$ HEPES, and 1\% Glutamax, and were incubated at $37^{\circ} \mathrm{C}$ with $5 \% \mathrm{CO}_{2}$ for $20 \mathrm{~min}$. These bacteria were used to inoculate RAW 264.7 in this same medium at an MOI of 10 .

\section{Authors' contributions}

$\mathrm{JH}$ wrote the manuscript, constructed plasmids and mutants, conducted the experiments, envisioned and designed the study. PEC designed the microarrays and contributed toward the execution of microarray experiments. DMO conducted the real time PCR. Both PEC and DMO assisted with the chicken embryo infections. RMQS constructed plasmids and participated in the drafting of the manuscript. GJN oversaw the work, contributed to the conception and design of this research, and participated in the drafting of this manuscript. All authors read and approved the final version of the manuscript.

\section{Additional material}

\section{Additional file 1}

Table S1. This table shows a list of F. tularensis LVS genes significantly induced at $37^{\circ} \mathrm{C}$.

Click here for file

[http://www.biomedcentral.com/content/supplementary/1471-

2180-8-172-S1.doc]

\section{Additional file 2}

Table S2. This table displays a list of F. tularensis LVS genes significantly down-regulated at $37^{\circ} \mathrm{C}$.

Click here for file

[http://www.biomedcentral.com/content/supplementary/1471-

2180-8-172-S2.doc]

\section{Acknowledgements}

We thank John W. Robison for technical assistance, and James Carroll, and Cory M. Robinson for insightful discussion. The authors thank Deanna Tarwacki for assistance with dendritic cell cultivation and infections. We also thank Francis E. Nano for helpful correspondence regarding the chicken embryo challenge model. We thank Thomas Zahrt and Martin Pavelka for providing us with plasmids and Karen Elkins for providing F. tularensis LVS. This work was funded by the National Institutes of Health grants Al074402 and Al0500 I8. JH is a recipient of T32 AI060525, "Immunology of Infectious Disease."

\section{References}

I. Ellis J, Oyston PC, Green M, Titball RW: Tularemia. Clin Microbiol Rev 2002, I 5(4):63I-646.

2. Sjostedt A: Tularemia: history, epidemiology, pathogen physiology, and clinical manifestations. Ann N Y Acad Sci 2007, I I 05: I-29.

3. Dennis DT, Inglesby TV, Henderson DA, Bartlett JG, Ascher MS, Eitzen $E$, Fine $A D$, Friedlander $A M$, Hauer J, Layton $M$, et al: Tularemia as a biological weapon: medical and public health management. Jama 200I, 285(2 I):2763-2773.

4. Berdal BP, Mehl R, Meidell NK, Lorentzen-Styr AM, Scheel O: Field investigations of tularemia in Norway. FEMS Immunol Med Microbiol I996, I3(3): 191-195.

5. Oyston PC, Quarry JE: Tularemia vaccine: past, present and future. Antonie Van Leeuwenhoek 2005, 87(4):277-28I.

6. Nano FE, Schmerk C: The Francisella pathogenicity island. Ann N Y Acad Sci 2007, I I 05: I 22- I 37.

7. Golovliov I, Ericsson M, Sandstrom G, Tarnvik A, Sjostedt A: Identification of proteins of Francisella tularensis induced during growth in macrophages and cloning of the gene encoding a prominently induced 23-kilodalton protein. Infect Immun 1997, 65(6):2183-2189.

8. Deng K, Blick RJ, Liu W, Hansen Ej: Identification of Francisella tularensis genes affected by iron limitation. Infect Immun 2006, 74(7):4224-4236.

9. Lenco J, Hubalek M, Larsson P, Fucikova A, Brychta M, Macela A, Stulik J: Proteomics analysis of the Francisella tularensis LVS response to iron restriction: induction of the $F$. tularensis pathogenicity island proteins IgIABC. FEMS Microbiol Lett 2007, 269(I): II-2I.

10. Sullivan JT, Jeffery EF, Shannon JD, Ramakrishnan G: Characterization of the siderophore of Francisella tularensis and role of $f$ sIA in siderophore production. I Bacteriol 2006, I 88( I I):3785-3795.

II. Carlson PE Jr, Carroll JA, O'Dee DM, Nau GJ: Modulation of virulence factors in Francisella tularensis determines human macrophage responses. Microb Pathog 2007, 42(5-6):204-2। 4.

12. Qin A, Mann BJ: Identification of transposon insertion mutants of Francisella tularensis tularensis strain Schu S4 deficient in 
intracellular replication in the hepatic cell line HepG2. BMC Microbiol 2006, 6:69.

13. Su J, Yang J, Zhao D, Kawula TH, Banas JA, Zhang JR: Genome-wide identification of Francisella tularensis virulence determinants. Infect Immun 2007, 75(6):3089-3 I0I.

14. Weiss DS, Brotcke A, Henry T, Margolis JJ, Chan K, Monack DM: In vivo negative selection screen identifies genes required for Francisella virulence. Proc Natl Acad Sci USA 2007, I 04( I 4):6037-6042.

15. Twine S, Bystrom M, Chen W, Forsman M, Golovliov I, Johansson A, Kelly J, Lindgren $\mathrm{H}$, Svensson $\mathrm{K}$, Zingmark $\mathrm{C}$, et al.: A mutant of Francisella tularensis strain SCHU S4 lacking the ability to express a 58-kilodalton protein is attenuated for virulence and is an effective live vaccine. Infect Immun 2005, 73(I 2):8345-8352.

16. Carroll JA, El-Hage N, Miller JC, Babb K, Stevenson B: Borrelia burgdorferi RevA antigen is a surface-exposed outer membrane protein whose expression is regulated in response to environmental temperature and $\mathrm{pH}$. Infect Immun 200I, 69(9):5286-5293.

17. Miller JF, Mekalanos JJ, Falkow S: Coordinate regulation and sensory transduction in the control of bacterial virulence. Science 1989, 243(4893):916-922.

18. Ojaimi C, Brooks C, Casjens S, Rosa P, Elias A, Barbour A, Jasinskas A, Benach J, Katona L, Radolf J, et al.: Profiling of temperatureinduced changes in Borrelia burgdorferi gene expression by using whole genome arrays. Infect Immun 2003, 7I(4): 1689-1705.

19. Smoot LM, Smoot JC, Graham MR, Somerville GA, Sturdevant DE, Migliaccio CA, Sylva GL, Musser JM: Global differential gene expression in response to growth temperature alteration in group A Streptococcus. Proc Natl Acad Sci USA 200I, 98(18):10416-10421.

20. Tobe T, Yoshikawa M, Sasakawa C: Thermoregulation of virB transcription in Shigella flexneri by sensing of changes in local DNA superhelicity. J Bacteriol 1995, I77(4): 1094-1097.

21. Hueck C): Type III protein secretion systems in bacterial pathogens of animals and plants. Microbiol Mol Biol Rev 1998, 62(2):379-433.

22. Zuber U, Schumann W: CIRCE, a novel heat shock element involved in regulation of heat shock operon dnaK of Bacillus subtilis. J Bacteriol 1994, I 76(5): I359-1363.

23. Straus DB, Walter WA, Gross CA: The heat shock response of $E$. coli is regulated by changes in the concentration of sigma 32. Nature 1987, 329(6I37):348-35।.

24. Konkel ME, Tilly K: Temperature-regulated expression of bacterial virulence genes. Microbes Infect 2000, 2(2):157-166.

25. Ericsson M, Golovliov I, Sandstrom G, Tarnvik A, Sjostedt A: Characterization of the nucleotide sequence of the gro $E$ operon encoding heat shock proteins chaperone- 60 and -10 of Francisella tularensis and determination of the T-cell response to the proteins in individuals vaccinated with $F$. tularensis. Infect Immun 1997, 65(5):1824-1829.

26. Ericsson M, Tarnvik A, Kuoppa K, Sandstrom G, Sjostedt A: Increased synthesis of DnaK, GroEL, and GroES homologs by Francisella tularensis LVS in response to heat and hydrogen peroxide. Infect Immun 1994, 62(I): I78-I83.

27. Meibom KL, Dubail I, Dupuis M, Barel M, Lenco J, Stulik J, Golovliov I, Sjostedt A, Charbit A: The heat-shock protein ClpB of Francisella tularensis is involved in stress tolerance and is required for multiplication in target organs of infected mice. Mol Microbiol 2008, 67(6): |384-| $40 \mid$.

28. Bhatnagar NB, Elkins KL, Fortier AH: Heat stress alters the virulence of a rifampin-resistant mutant of Francisella tularensis LVS. Infect Immun I995, 63(I): I54-I59.

29. Shaffer SA, Harvey MD, Goodlett DR, Ernst RK: Structural heterogeneity and environmentally regulated remodeling of Francisella tularensis subspecies novicida lipid A characterized by tandem mass spectrometry. J Am Soc Mass Spectrom 2007, I 8(6): 1080-1092.

30. Mohapatra NP, Balagopal A, Soni S, Schlesinger LS, Gunn JS: AcpA is a Francisella acid phosphatase that affects intramacrophage survival and virulence. Infect Immun 2007, 75(I):390-396.

31. Patel S, Lyons-Weiler J: caGEDA: a web application for the integrated analysis of global gene expression patterns in cancer. Appl Bioinformatics 2004, 3(I):49-62.
32. Altschul SF, Madden TL, Schaffer AA, Zhang J, Zhang Z, Miller W, Lipman DJ: Gapped BLAST and PSI-BLAST: a new generation of protein database search programs. Nucleic Acids Res 1997, 25(I 7):3389-3402.

33. Falquet L, Pagni M, Bucher P, Hulo N, Sigrist CJ, Hofmann K, Bairoch A: The PROSITE database, its status in 2002. Nucleic Acids Res 2002, 30(I):235-238.

34. Blaser MJ: Role of vacA and the cagA locus of Helicobacter pylori in human disease. Aliment Pharmacol Ther 1996, I0(Suppl I):73-77.

35. Xiang Z, Censini S, Bayeli PF, Telford JL, Figura N, Rappuoli R, Covacci $A$ : Analysis of expression of CagA and VacA virulence factors in 43 strains of Helicobacter pylori reveals that clinical isolates can be divided into two major types and that CagA is not necessary for expression of the vacuolating cytotoxin. Infect Immun 1995, 63(1):94-98.

36. Townsend MK, Carr NJ, lyer JG, Horne SM, Gibbs PS, Pruss BM: Pleiotropic phenotypes of a Yersinia enterocolitica flhD mutant include reduced lethality in a chicken embryo model. $B M C$ Microbiol 2008, 8: 12.

37. Nix EB, Cheung KK, Wang D, Zhang N, Burke RD, Nano FE: Virulence of Francisella spp. in chicken embryos. Infect Immun 2006, 74(8):4809-48।6.

38. de Bruin OM, Ludu JS, Nano FE: The Francisella pathogenicity island protein IgIA localizes to the bacterial cytoplasm and is needed for intracellular growth. BMC Microbiol 2007, 7:1.

39. Herren CD, Mitra A, Palaniyandi SK, Coleman A, Elankumaran S, Mukhopadhyay S: The BarA-UvrY two-component system regulates virulence in avian pathogenic Escherichia coli O78:K80:H9. Infect Immun 2006, 74(8):4900-4909.

40. Siatskas C, Boyd R: Regulation of chicken haemopoiesis by cytokines. Dev Comp Immunol 2000, 24(I):37-59.

4I. Tozzi MG, Camici M, Mascia L, Sgarrella F, Ipata PL: Pentose phosphates in nucleoside interconversion and catabolism. Febs 2006, 273(6): 1089-II0I.

42. Hammer-Jespersen K, Munch-Petersen A: Phosphodeoxyribomutase from Escherichia coli. Purification and some properties. Eur J Biochem 1970, I 7(3):397-407.

43. Titball RW, Petrosino JF: Francisella tularensis genomics and proteomics. Ann N Y Acad Sci 2007, I I 05:98-I2I.

44. Sjostedt A: Intracellular survival mechanisms of Francisella tularensis, a stealth pathogen. Microbes Infect 2006, 8(2):56I-567.

45. Lauriano CM, Barker JR, Yoon SS, Nano FE, Arulanandam BP, Hassett DJ, Klose KE: MgIA regulates transcription of virulence factors necessary for Francisella tularensis intraamoebae and intramacrophage survival. Proc Natl Acad Sci USA 2004, I01( (12):4246-4249.

46. Brotcke A, Weiss DS, Kim CC, Chain P, Malfatti S, Garcia E, Monack DM: Identification of MgIA-regulated genes reveals novel virulence factors in Francisella tularensis. Infect Immun 2006, 74(I 2):6642-6655

47. Clemens DL, Lee BY, Horwitz MA: Francisella tularensis enters macrophages via a novel process involving pseudopod loops. Infect Immun 2005, 73(9):5892-5902.

48. Ben Nasr A, Haithcoat J, Masterson JE, Gunn JS, Eaves-Pyles T, Klimpel GR: Critical role for serum opsonins and complement receptors CR3 (CDIIb/CDI8) and CR4 (CDIIc/CDI8) in phagocytosis of Francisella tularensis by human dendritic cells (DC): uptake of Francisella leads to activation of immature DC and intracellular survival of the bacteria. J Leukoc Biol 2006, 80(4):774-786.

49. Schulert GS, Allen LA: Differential infection of mononuclear phagocytes by Francisella tularensis: role of the macrophage mannose receptor. J Leukoc Biol 2006, 80(3):563-57I.

50. Balagopal A, MacFarlane AS, Mohapatra N, Soni S, Gunn JS, Schlesinger LS: Characterization of the receptor-ligand pathways important for entry and survival of Francisella tularensis in human macrophages. Infect Immun 2006, 74(9):5I I4-5I 25

51. Chamberlain RE: Evaluation of Live Tularemia Vaccine Prepared in a Chemically Defined Medium. Appl Microbiol 1965, 13:232-235.

52. Golub TR, Slonim DK, Tamayo P, Huard C, Gaasenbeek M, Mesirov JP, Coller H, Loh ML, Downing JR, Caligiuri MA, et al:: Molecular classification of cancer: class discovery and class prediction by gene expression monitoring. Science 1999, 286(5439):53I-537. 
53. Rozen S, Skaletsky H: Primer3 on the WWW for general users and for biologist programmers. Methods Mol Biol 2000, I32:365-386.

54. Horzempa J, Comer JE, Davis SA, Castric P: Glycosylation substrate specificity of Pseudomonas aeruginosa I 244 pilin. J Biol Chem 2006, 28 I(2): I I28- I I36.

55. Shanks RM, Caiazza NC, Hinsa SM, Toutain CM, O'Toole GA: Saccharomyces cerevisiae-based molecular tool kit for manipulation of genes from gram-negative bacteria. Appl Environ Microbiol 2006, 72(7):5027-5036.

56. Golovliov I, Sjostedt A, Mokrievich A, Pavlov V: A method for allelic replacement in Francisella tularensis. FEMS Microbiol Lett 2003, 222(2):273-280.

57. Horzempa J, Tarwacki DM, Carlson PE Jr, Robinson CM, Nau GJ: Characterization and application of a glucose-repressible promoter in Francisella tularensis. Appl Environ Microbiol 2008, 74(7):2 $161-2170$.

58. Edelstein PH, Hu B, Shinzato T, Edelstein MA, Xu W, Bessman MJ: Legionella pneumophila NudA Is a Nudix hydrolase and virulence factor. Infect Immun 2005, 73( I 0):6567-6576.

59. Smedley JG 3rd, Jewell E, Roguskie J, Horzempa J, Syboldt A, Stolz DB Castric P: Influence of pilin glycosylation on Pseudomonas aeruginosa I244 pilus function. Infect Immun 2005 73( I 2):7922-793।.

60. Robinson CM, Nau GJ: Interleukin-I 2 and Interleukin-27 Regulate Macrophage Control of Mycobacterium tuberculosis. J Infect Dis 2008, I 98(3):359-366.

6I. Tachado SD, Zhang J, Zhu J, Patel N, Cushion M, Koziel H: Pneumocystis-mediated IL-8 release by macrophages requires coexpression of mannose receptors and TLR2. J Leukoc Biol 2007, 8I(I):205-2II.

62. Lai XH, Golovliov I, Sjostedt A: Expression of IgIC is necessary for intracellular growth and induction of apoptosis in murine macrophages by Francisella tularensis. Microb Pathog 2004, 37(5):225-230.

63. Maier TM, Havig A, Casey M, Nano FE, Frank DW, Zahrt TC: Construction and characterization of a highly efficient Francisella shuttle plasmid. Appl Environ Microbiol 2004, 70:751 I-75I9.

64. Ruvkun G, Ausubel FM: A general method for site-directed mutagenesis in prokaryotes. Nature I98I, 289:85-88.

65. LoVullo ED, Sherrill LA, Perez LL, Pavelka MS Jr: Genetic tools for highly pathogenic Francisella tularensis subsp. tularensis. Microbiology 2006, I 52(Pt I I):3425-3435.

66. Tempel R, Lai XH, Crosa L, Kozlowicz B, Heffron F: Attenuated Francisella novicida transposon mutants protect mice against wild-type challenge. Infect Immun 2006, 74(9):5095-5I 05.

67. Gray CG, Cowley SC, Cheung KK, Nano FE: The identification of five genetic loci of Francisella novicida associated with intracellular growth. FEMS Microbiol Lett 2002, 2 I 5(I):53-56.

68. Maier TM, Casey MS, Becker RH, Dorsey CW, Glass EM, Maltsev N, Zahrt TC, Frank DW: Identification of Francisella tularensis Himar I-based transposon mutants defective for replication in macrophages. Infect Immun 2007, 75(I I):5376-5389.

69. Charity JC, Costante-Hamm MM, Balon EL, Boyd DH, Rubin EJ, Dove SL: Twin RNA Polymerase-Associated Proteins Control Virulence Gene Expression in Francisella tularensis. PLoS Pathog 2007, 3(6):e84.
Publish with Bio Med Central and every scientist can read your work free of charge

"BioMed Central will be the most significant development for disseminating the results of biomedical research in our lifetime. "

Sir Paul Nurse, Cancer Research UK

Your research papers will be:

- available free of charge to the entire biomedical community

- peer reviewed and published immediately upon acceptance

- cited in PubMed and archived on PubMed Central

- yours - you keep the copyright
BioMedcentral 